\title{
Effect of biofertilizers on soil microbial count, nutrient availability and uptake under november sown onion
}

\author{
Dilpreet Talwar $^{1 *}$, Kulbir Singh ${ }^{1}$ and Jagdish Singh ${ }^{2}$ \\ ${ }^{1}$ Department of Vegetable Science, Punjab Agricultural University, Ludhiana- 141004 (Punjab), INDIA \\ ${ }^{2}$ Department of Soil Science, Punjab Agricultural University, Ludhiana -141004 (Punjab), INDIA \\ *Corresponding author. E-mail: dsingh381@gmail.com
}

Received: May 9, 2016; Revised received: August 12, 2016; Accepted: January 6, 2017

\begin{abstract}
Biofertilizers improves the soil microbial content, Soil nutrient status and nutrient uptake by plant. In an experiment, fifteen treatments comprised of various combinations of biofertilizers, organic manures and chemical fertilizers were compared to access the impact of different sources of nutrient on performance of onion. The highest soil organic carbon (0.40\%) was observed in the treatments $T_{12}$ (Farm Yard Manure (FYM) @ 20 t/ha) and $T_{11}$ (FYM @ 20 t/ha + Azotobacter + Vesicular-Arbuscular Mycorrhizae (VAM)). Highest bacterial (24.5 X 10 ${ }^{6}$ ) and actinomyctes count $\left(29.9 \times 10^{4}\right)$ was recorded in $\mathrm{T}_{11}$ (FYM @ $20 \mathrm{t} / \mathrm{ha}+$ Azotobacter + VAM) treatment while highest fungal count $\left(17.5 \times 10^{3}\right)$ was observed in $\mathrm{T}_{3}$ (Azospirillium + Recommended dose of NPK) treatment. At the time of harvesting, available nitrogen $(\mathrm{N})$, Available phosphorus $(\mathrm{P})$ and Available potassium $(\mathrm{K})$ were higher in treatment $\mathrm{T}_{3}$ (Azospirillium + Recommended dose of NPK), $\mathrm{T}_{9}$ (Azotobacter + VAM + Recommended dose of NPK) and $\mathrm{T}_{13}$ (Poultry Manure @ 5t/ha) treatments respectively than that in other treatments. Azospirillum and Azotobacter application along with recommended dose of $\mathrm{N}, \mathrm{P}$ and $\mathrm{K}$ improved the fertility status of soil. The $\mathrm{N}$ uptake was significantly higher in $T_{3}$ treatment $\left(162.6 \mathrm{Kg} \mathrm{ha}^{-1}\right)$ as compared to all other treatments except $T_{1}$ and $T_{9}$ treatments while $P$ uptake $\left(13.6 \mathrm{Kg} \mathrm{ha}^{-1}\right)$ was significantly higher in $T_{9}$ treatment than that in other treatments except $T_{1}, T_{3}, T_{5}$ and $T_{7}$ treatments. The $\mathrm{K}$ uptake was significantly higher in $\mathrm{T}_{3}$ treatment $\left(126.9 \mathrm{Kg} \mathrm{ha}{ }^{-1}\right)$ as compare to all other treatments except $T_{1}$ and $T_{9}$ treatments. The present study highlights the need of use of biofertilizers along with organic and inorganic manures/fertilizer to enhance the nutrient availability and improve soil health.
\end{abstract}

Keywords: Chemical fertilizers, Nutrient uptake, Organic carbon, Organic manures, Vesicular-Arbuscular mycorrhizae

\section{INTRODUCTION}

Onion is used in raw form as well as in dehydrated form to add flavor and taste to Indian foods as a culinary ingredient in wide range of food preparations. It is also used as salad. Onion is also a rich source of minerals like phosphorus, calcium, vitamin $\mathrm{C}$, protein and carbohydrates. Onion is used in pharmaceutical preparations due to its medicinal values. Onion is also known to cure heart diseases as it checks the deposition of cholesterol in blood vessels (Barakade et al., 2011). India is the second largest producer of onion (with area of 117.4 thousand hectare and production of 203.3 lakh tonnes) in the world next only to China and third largest exporter after Netherland and Spain (Anonymous, 2016a). In Punjab, it is cultivated over an area of 8264 hectare with a production of 183 thousand metric tonnes and average productivity of 22.3 tons per hectare (Anonymous, 2016b).

Onion is a shallow rooted and high nutrient demanding vegetable; its productivity depends on soil fertility status and nutrients applied. Under inadequate fertilization considerable yield losses have been reported (Balemi et al., 2007). The increasing cost and decreasing availability of inorganic fertilizers in peak periods is making crop production uneconomical particularly for small and marginal farmers. Therefore it is essential to evolve and adopt a suitable strategy for integrated nutrient supply by using combination of inorganic fertilizers, organic manures and biofertilizers. The use of nitrogen fixing microbes will help in reducing the dependence on urea, while phosphorus solubilizing microbes will increase the availability of $\mathrm{P}$ from relatively unavailable pools, thus use of integrated source of nutrients will help in curtailing over dependence on inorganic fertilizers alone for nutrient supply to onion.

Biofertilizers are products containing live or latent microorganisms that are capable of mobilizing nutrients from unavailable form to available form through biological processes (Gaur, 2010). Proper use of biofertilizers on farm organic wastes and microbial inoculants help in maintaining the fertility of agricultural soils (Kannaiyan, 2002). Azotobacter and Azospirillium are free living bacteria which colonize near the root zone and enhance the available nitrogen in the soil by $\mathrm{N}$ fixation, whereas phosphate solubilizing bacteria (PSB) solublize the unavailable phosphorus in 
the soil and make it available for the plants (Devi et al., 2003, Gupta and Samnotra, 2004, Yadav et al., 2004, Singh and Singh, 2007, Kachari and Korla, 2009).Vesicular-Arbuscular Mycorrhizae (VAM) help in the development of stronger root system, increase root surface area, improve growth (Zandavalli et al., 2004), nutrient uptake and increased tolerance of host roots to soil borne pathogens (Nelson and Achar, 2001, Singh and Singh, 2007). The present investigation was initiated to access the effect of biofertilizers, organic manures and synthetic fertilizers on microbial count, nutrient availability and uptake by onion plant.

\section{MATERIALS AND METHODS}

The present investigation was carried out at Vegetable Research Farm of Punjab Agricultural University, Ludhiana during the rabi season 2013-14. The soil was loamy sand in texture with $\mathrm{pH}$ 7.6. Soil was low in organic carbon and nitrogen, high in phosphorus and medium in potassium. The onion cultivar Punjab Naroya was sown in nursery beds during November and transplanted in January with space of $15 \mathrm{~cm} \mathrm{X} 7.5$ $\mathrm{cm}$ between rows and plants respectively. The experiment was carried out in a randomized block design with fifteen treatments replicated thrice. The detail of treatments has been given in Table 1 .

Organic carbon was determined by Walkley and Black method (1934). Bacterial count was determined by using serial dilution pour plate method (Gerhardt et al., 1981). Actinomycetes count was determined by using serial dilution pour plate method (Nonomura and Ohara, 1969). Fungi count was determined by using serial dilution pour plate method (Kanwar et al., 1997). Available Nitrogen in soil was estimated by alkaline potassium permanganate method by Subbiah and Asija (1965). Available Phosphorus in soil was estimated by method given by Olsen et al. (1954). Available Potassium in soil was estimated with ammonium acetate and estimated by Hange's flame photometer (Jackson, 1967).

The N, P and K uptake by bulb was computed by multiplying the percentage $\mathrm{N}, \mathrm{P}$ and $\mathrm{K}$ content in bulb with bulb dry mass as given in the equation.

Nutrient uptake by bulb $\left(\mathrm{Kg} \mathrm{ha}^{-1}\right)=$ nutrient content (\%) x bulb dry mass $\left(\mathrm{Kg} \mathrm{ha}^{-1}\right)$

Plant N, P and K uptake was computed by multiplying the $\mathrm{N}, \mathrm{P}$ and $\mathrm{K}$ content with plant dry mass. Finally total $\mathrm{N}, \mathrm{P}$ and $\mathrm{K}$ uptake was calculated by sum of $\mathrm{N}, \mathrm{P}$ and $\mathrm{K}$ uptake by bulbs and $\mathrm{N}, \mathrm{P}$ and $\mathrm{K}$ uptake by plants, respectively.

\section{RESULTS AND DISCUSSION}

Microbial count of soil at the time of transplanting and harvesting: At the time of transplanting, organic carbon in the soil was 0.26 per cent, bacterial count was $20.5 \times 10^{6}$, Actinomyctes count was $24.3 \times 10^{4}$ and fungus count was $15 \times 10^{3}$ (Table 2). After harvesting, biofertilizers improved the soil organic carbon status and highest soil organic carbon was found in $\mathrm{T}_{12}$ (FYM @ $20 \mathrm{t} \mathrm{ha}^{-1}$ ) andT T $_{11}$ (FYM @ $20 \mathrm{t}$ ha $^{-1}$ along with Azotobacter and VAM) that was 0.40 per cent followed by $\mathrm{T}_{13}$ (Poultry manure @ $\mathrm{t} \mathrm{ha}^{-1}$ ) that was 0.38 per cent. Highest number of bacteria was found in $\mathrm{T}_{11}$ where FYM along with Azotobacter and VAM was applied $\left(24.5 \times 10^{6}\right)$ followed by $\mathrm{T}_{13}$ where poultry manure was applied @ $5 \mathrm{t} \mathrm{ha}^{-1}\left(23.8 \times 10^{6}\right)$ (Table 2). Highest number of Actinomyctes were found in treatment $\mathrm{T}_{11}$ (FYM along with Azotobacter and VAM) that was $29.9 \times 10^{4}$ and $\mathrm{T}_{12}$ (FYM@ $20 \mathrm{t}$ $\mathrm{ha}^{-1}$ ) that was $29.1 \mathrm{X}^{4} 0^{4}$. The application of Azospirillum along with recommended dose of fertilizers $\left(\mathrm{T}_{3}\right)$ had highest number of fungi microorganism (17.5 X $\left.10^{3}\right)$ at the time of harvesting followed by $\mathrm{T}_{7}(16.8 \mathrm{X}$ $10^{3}$ ) where VAM along with recommended dose of fertilizers was applied (Table 2). Thus, biofertilizers had improved the microorganisms in the soil. FYM treatments improved the microbial count at harvesting time due to slow releasing of nutrients. The plots without inoculation of biofertilizers and application of chemical fertilizer did not differ significantly than inoculated ones initially at time of transplanting. At harvesting, application of chemical fertilizer alone showed lower microbial count for bacterial group compared to inoculated ones. The results corroborate with the finding of Mandic et al. (2011) and Javoreková et al. (2015) who reported that the application of biofertilizers alone with organic manures resulted in enhanced microbial activity.

Nutrient status of soil: At the time of transplanting $\mathrm{N}$ level in soil was $140 \mathrm{~kg} \mathrm{ha}^{-1}$, P level was $32 \mathrm{~kg} \mathrm{ha}^{-1}$ and $\mathrm{K}$ level was $150 \mathrm{~kg} \mathrm{ha}^{-1}$. $\mathrm{N}$ level in soil at time of harvesting was maximum in treatment $\mathrm{T}_{3}$ (Azospirillum and recommended dose of N, P and $\mathrm{K}$ ) that was $156 \mathrm{~kg} \mathrm{ha}{ }^{-1}$ followed by treatment $\mathrm{T}_{1}$ (Azotobacter along with recommended dose of fertilizers) that was $154 \mathrm{~kg} \mathrm{ha}^{-1}$, treatment $\mathrm{T}_{9}$ (Azotobacter along with VAM and recommended dose of $\mathrm{N}, \mathrm{P}$ and $\mathrm{K}$ ) and treatment $\mathrm{T}_{12}\left(\mathrm{FYM} @ 20 \mathrm{t} \mathrm{ha}^{-1}\right.$ ) that was $150 \mathrm{~kg} \mathrm{ha}^{-1}$ and minimum level of $\mathrm{N}$ in soil was found in treatment $\mathrm{T}_{15}$ (control) that was $136 \mathrm{~kg} \mathrm{ha}^{-1}$ (Table 2). While $\mathrm{P}$ level was found maximum in treatment $\mathrm{T}_{9}$ (Azotobacter along with VAM and recommended dose of $\mathrm{N}, \mathrm{P}$ and $\mathrm{K}$ ) that was $42 \mathrm{~kg} \mathrm{ha}^{-1}$ followed by treatment $\mathrm{T}_{7}$ (VAM along with recommended dose of fertilizers), treatment $\mathrm{T}_{11}$ (FYM @ $20 \mathrm{t} \mathrm{ha}^{-1}$ along with Azotobacter and VAM) and treatment $\mathrm{T}_{13}$ (Poultry Manure @ 5 $\mathrm{t} \mathrm{ha}^{-1}$ ) that was $40 \mathrm{~kg} \mathrm{ha}^{-1}$ and minimum level of $\mathrm{P}$ in soil was found in treatment $\mathrm{T}_{15}$ (control) that was $30 \mathrm{~kg} \mathrm{ha}^{-1}$. While $\mathrm{K}$ level was found maximum in treatment $\mathrm{T}_{13}$ (poultry manure @ $5 \mathrm{t} \mathrm{ha}^{-1}$ ) that was $160 \mathrm{~kg} \mathrm{ha}^{-1}$ followed by treatment $\mathrm{T}_{11}$ (FYM @ $20 \mathrm{t} \mathrm{ha}^{-1}$ along with Azotobacter and VAM) and treatment $\mathrm{T}_{12}$ (FYM @ $20 \mathrm{t} \mathrm{ha}^{-1}$ ) that was $158 \mathrm{~kg} \mathrm{ha}^{-1}$ and minimum level of $\mathrm{K}$ in soil was found in treatment $\mathrm{T}_{15}$ (control) that was 
Table 1. Detail of treatments

\begin{tabular}{|c|c|}
\hline Treatments & Treatment detail \\
\hline $\mathrm{T}_{1}$ & Azotobacter + Recommended dose of NPK \\
\hline $\mathrm{T}_{2}$ & Azotobacter $+75 \%$ of recommended dose of $\mathrm{N}+$ Recommended dose of PK \\
\hline $\mathrm{T}_{3}$ & Azospirillium + Recommended dose of NPK \\
\hline $\mathrm{T}_{4}$ & Azospirillium $+75 \%$ of recommended dose of $\mathrm{N}+$ Recommended dose of PK \\
\hline $\mathrm{T}_{5}$ & Phosphate Solubilizing Bacteria (PSB) + Recommended dose of NPK \\
\hline $\mathrm{T}_{6}$ & $\begin{array}{l}\text { Phosphate Solubilizing Bacteria (PSB) }+75 \% \text { of recommended dose of P }+ \text { Recommended dose } \\
\text { of NK }\end{array}$ \\
\hline $\mathrm{T}_{7}$ & Vesicular-Arbuscular Mycorrhizae (VAM) + Recommended dose of NPK \\
\hline $\mathrm{T}_{8}$ & $\begin{array}{l}\text { Vesicular-Arbuscular Mycorrhizae (VAM) }+75 \% \text { of recommended dose of } \mathrm{P}+\text { recommended } \\
\text { dose of NK }\end{array}$ \\
\hline $\mathrm{T}_{9}$ & Azotobacter + Vesicular-Arbuscular Mycorrhizae $(\mathrm{VAM})+$ Recommended dose of NPK \\
\hline $\mathrm{T}_{10}$ & $\begin{array}{l}\text { Azotobacter }+ \text { Vesicular-Arbuscular Mycorrhizae }(\mathrm{VAM})+75 \% \text { of recommended dose of } \mathrm{N}+ \\
75 \% \text { recommended dose of } \mathrm{P}+\text { recommended dose of } \mathrm{K}\end{array}$ \\
\hline $\mathrm{T}_{11}$ & FYM @ 20 t/ha + Azotobacter + Vesicular-Arbuscular Mycorrhizae (VAM) \\
\hline $\mathrm{T}_{12}$ & FYM @ 20 t/ha \\
\hline $\mathrm{T}_{13}$ & Poultry Manure@5t/ha \\
\hline $\mathrm{T}_{14}$ & Recommended dose of NPK \\
\hline $\mathrm{T}_{15}$ & Control \\
\hline
\end{tabular}

Recommended dose of fertilizers (100:50:50, N: P: K kg per hectare).

$146 \mathrm{~kg} \mathrm{ha}^{-1}$ (Table 2).

Biofertilizers improved the $\mathrm{N}$ status of the soil due to $\mathrm{N}$ fixation by Azotobacter and Azospirillum. These bacterium convert the unavailable form of nitrogen (nitrate) to available form of nitrogen (nitrite), thus improved the nitrogen availability in the soil (Kalyani et al.,1992). PSB and VAM improved the phosphorus status in the soil by solublization process. PSB and VAM solublize the unavailable form of phosphorus into available form (Jayathilake et al., 2002). Our results are in conformity with Mengistu and Singh (1999). Biofertilization had moderately enhanced the fertility level of the soil after crop harvest. Application of Azospirillum and VAM resulted in increase $13.81 \%$ soil $\mathrm{N}$ and $13.41 \%$ soil $\mathrm{P}$ as compared to initial fertility status of the soil of onion crop. Similarly, Nelson and Achar (2001), Devi et al. (2003), Yadav et al., (2004), Gupta and Samnotra (2004), Singh and Singh (2007) and Kachari and Korla (2009) also reported increase in soil $\mathrm{N}$ and $\mathrm{P}$ with the application of biofertilizers alone with manures.

\section{Nutrient uptake}

Total nitrogen uptake: The data pertaining to the effect of different treatments on the total uptake of $\mathrm{N}$, $\mathrm{P}$ and $\mathrm{K}$ nutrients has been presented in Table 3 . Application of Azospirillum along with recommended dose of $\mathrm{N}, \mathrm{P}$ and $\mathrm{K}(100 \mathrm{Kg} \mathrm{N}, 50 \mathrm{Kg} \mathrm{P}$ and $50 \mathrm{Kg} \mathrm{K}$ per $\left.\mathrm{ha}^{-1}\right)$ resulted in maximum total nitrogen uptake (162.6 Kg ha ${ }^{-1}$ ) which was statistically at par with Azotobacter along with recommended dose of fertilizers $\left(\mathrm{T}_{1}\right)$ and Azotobacter along with VAM and recommended dose of fertilizers $\left(\mathrm{T}_{9}\right)$ and was significantly higher from rest of treatments. Among organic manure, maximum $\mathrm{N}$ uptake was recorded with farm yard manure $\left(\mathrm{T}_{12}\right)$ that was $115.2 \mathrm{Kg} \mathrm{ha}^{-1}$ but the difference among other organic manure treatments was non-significant. Total $\mathrm{N}$ uptake attained with treatment $\mathrm{T}_{14}$ where recommended dose of fertilizers $\left(105.7 \mathrm{~kg} \mathrm{ha}^{-1}\right)$ was significantly higher than treatment $\mathrm{T}_{15}\left(53.3 \mathrm{~kg} \mathrm{ha}^{-1}\right)$ where no fertilizer was applied.

Total phosphorus uptake: The maximum total phosphorus uptake of $13.6 \mathrm{Kg} \mathrm{ha}^{-1}$ was attained in treatment $\mathrm{T}_{9}$ followed by treatment $\mathrm{T}_{6}$ (PSB along with recommended dose of fertilizers) that was $12.6 \mathrm{Kg} \mathrm{ha}^{-1}$ which was significantly higher than rest of treatments except treatment $\mathrm{T}_{1}, \mathrm{~T}_{3}, \mathrm{~T}_{5}$ and $\mathrm{T}_{7}$. The minimum total uptake of $2.9 \mathrm{Kg} \mathrm{ha}^{-1}$ phosphorus was observed in control $\left(T_{15}\right)$ that was significantly lower from treatment $\mathrm{T}_{9}$ where maximum $\mathrm{P}$ content was found. Total uptake of $\mathrm{P}$ attained with application of recommended dose of fertilizers $\left(\mathrm{T}_{14}\right)$ was statistically at par with treatment $T_{15}$.

Total potassium uptake: Application of Azospirillum along with $\mathrm{N}, \mathrm{P}$ and $\mathrm{K}\left(\mathrm{T}_{3}\right)$ resulted in maximum total potassium uptake of $126.9 \mathrm{Kg} \mathrm{ha}^{-1}$ (Table 3 ) which was significantly higher than rest of treatments except $\mathrm{T}_{1}$ and $\mathrm{T}_{9}$. Minimum total potassium uptake of $59.8 \mathrm{Kg} \mathrm{ha}^{-1}$ was observed in control. Total $\mathrm{K}$ uptake attained with $\mathrm{T}_{14}$ where recommended dose of fertilizers $\left(86.3 \mathrm{Kg} \mathrm{ha}^{-1}\right)$ was significantly higher from $\mathrm{T}_{15}$ where no fertilizer $\left(59.8 \mathrm{~kg} \mathrm{ha}^{-1}\right)$ was applied.

The application of full dose of nitrogen along Azospirillum and Azotobacter showed significantly higher total nitrogen uptake as compared to reduced 
Dilpreet Talwar et al. / J. Appl. \& Nat. Sci. 9 (1): 55 - 59 (2017)

Table 2. Effect of different treatments on Microbial count and Nutrient status of soil at the time of transplanting and harvesting

\begin{tabular}{|c|c|c|c|c|c|c|c|}
\hline \multirow[b]{2}{*}{ Treatments } & \multirow{2}{*}{$\underset{\%}{\text { O.C. }}$} & \multicolumn{3}{|c|}{ Microbial count } & \multicolumn{3}{|c|}{ Soil nutrient status $(\mathrm{kg} / \mathrm{ha})$} \\
\hline & & $\begin{array}{c}\text { Bacterial } \\
\quad\left(10^{6}\right)\end{array}$ & $\begin{array}{l}\text { Actinomyctes } \\
\qquad\left(10^{4}\right)\end{array}$ & $\begin{array}{c}\text { Fungi } \\
\left(10^{3}\right)\end{array}$ & $\mathbf{N}$ & $\mathbf{P}$ & $\mathbf{K}$ \\
\hline At Transplanting time & 0.26 & 20.5 & 24.3 & 15.0 & 140 & 32 & 150 \\
\hline \multicolumn{8}{|l|}{ At harvesting time } \\
\hline $\mathrm{T}_{1}$ & 0.30 & 19.2 & 25.8 & 16.3 & 154 & 38 & 155 \\
\hline $\mathrm{T}_{2}$ & 0.28 & 18.3 & 25.1 & 15.2 & 145 & 35 & 150 \\
\hline $\mathrm{T}_{3}$ & 0.31 & 20.2 & 26.3 & 17.5 & 156 & 36 & 156 \\
\hline $\mathrm{T}_{4}$ & 0.28 & 22.4 & 26.1 & 17.0 & 146 & 34 & 148 \\
\hline $\mathrm{T}_{5}$ & 0.32 & 21.7 & 28.0 & 16.5 & 142 & 38 & 150 \\
\hline $\mathrm{T}_{6}$ & 0.27 & 19.4 & 27.4 & 16.1 & 140 & 36 & 146 \\
\hline $\mathrm{T}_{7}$ & 0.31 & 19.6 & 26.6 & 16.8 & 148 & 40 & 152 \\
\hline $\mathrm{T}_{8}$ & 0.28 & 19.1 & 26.2 & 16.2 & 145 & 35 & 148 \\
\hline $\mathrm{T}_{9}$ & 0.30 & 20.8 & 26.8 & 16.1 & 150 & 42 & 156 \\
\hline $\mathrm{T}_{10}$ & 0.28 & 20.4 & 26.2 & 16.3 & 146 & 38 & 155 \\
\hline $\mathrm{T}_{11}$ & 0.40 & 24.5 & 29.9 & 16.2 & 150 & 40 & 158 \\
\hline $\mathrm{T}_{12}$ & 0.40 & 23.7 & 29.1 & 15.7 & 150 & 38 & 158 \\
\hline $\mathrm{T}_{13}$ & 0.38 & 23.8 & 28.3 & 16.1 & 148 & 40 & 160 \\
\hline $\mathrm{T}_{14}$ & 0.32 & 19.1 & 23.9 & 16.7 & 142 & 36 & 152 \\
\hline $\mathrm{T}_{15}$ & 0.26 & 20.5 & 24.3 & 15.0 & 136 & 30 & 146 \\
\hline
\end{tabular}

Table 3. Effect of different treatments on total nutrient uptake of onion

\begin{tabular}{cccc}
\hline \multirow{2}{*}{ Treatments } & \multicolumn{3}{c}{ Nutrient uptake $\left(\mathbf{K g ~ h a ~}^{\mathbf{- 1}}\right)$} \\
\cline { 2 - 4 } & Total $\mathbf{~}$ & Total $\mathbf{P}$ & Total $\mathbf{~}$ \\
\hline $\mathrm{T}_{1}$ & 154.0 & 11.5 & 119.9 \\
$\mathrm{~T}_{2}$ & 119.5 & 9.4 & 108.4 \\
$\mathrm{~T}_{3}$ & 162.6 & 12.4 & 126.9 \\
$\mathrm{~T}_{4}$ & 133.8 & 10.1 & 105.8 \\
$\mathrm{~T}_{5}$ & 87.7 & 12.6 & 102.1 \\
$\mathrm{~T}_{6}$ & 78.7 & 8.6 & 95.9 \\
$\mathrm{~T}_{7}$ & 109.2 & 12.0 & 104.9 \\
$\mathrm{~T}_{8}$ & 76.5 & 8.8 & 84.8 \\
$\mathrm{~T}_{9}$ & 142.1 & 13.6 & 125.4 \\
$\mathrm{~T}_{10}$ & 5.9 & 91.9 \\
$\mathrm{~T}_{11}$ & 103.2 & 5.1 & 82.8 \\
$\mathrm{~T}_{12}$ & 103.1 & 5.6 & 86.1 \\
$\mathrm{~T}_{13}$ & 115.2 & 6.5 & 84.0 \\
$\mathrm{~T}_{14}$ & 98.8 & 4.9 & 86.3 \\
$\mathrm{~T}_{15}$ & 105.7 & 2.9 & 59.8 \\
$\mathrm{CD}(\mathrm{P}=0.05)$ & 53.3 & 3.26 & 13.4 \\
\hline
\end{tabular}

nitrogen application. The higher total nitrogen uptake could be due to the improved availability of nitrogen to plants due to $\mathrm{N}$ fixation by biofertilizers that helped in improvement vegetative growth and reproductive cycle. This may also be due to increased dry matter production due to the effects of plant growth substances and nitrogen fixation or assimilation by Azospirillum (Devi et al., 2003, Gupta and Samnotra, 2004). Increase in P uptake with application of PSB and VAM may be attributed to accelerated root development and enhanced root surface area which might have resulted 
in effective mining of soil phosphorus and higher availability of P in soil (Kachari and Korla, 2009).

\section{Conclusion}

The inorganic/chemical fertilizers are costly, result in soil and environmental pollution and also pose human health hazards, while, biofertilizers are eco-friendly, non-toxic and relatively cheaper natural products. The integrated use of biofertilizers along with organic and inorganic manures/fertilizers will help in improving nutrient use efficiency, protect nutrients against losses (such as leaching and volatilization losses) and reduce soil and environmental degradation. The results revealed that highest soil organic carbon $(0.40 \%)$ was observed in the treatments $\mathrm{T}_{12}$ and $\mathrm{T}_{11}$. Highest bacterial and actinomyctes count was recorded in $\mathrm{T}_{11}$ treatment while highest fungal count $\left(17.5 \times 10^{3}\right)$ was observed in $\mathrm{T}_{3}$ treatment. The soil available nitrogen $(\mathrm{N})$, Available phosphorus (P) and Available potassium (K) were higher in treatment $\mathrm{T}_{3}, \mathrm{~T}_{9}$ and $\mathrm{T}_{13}$ treatments, respectively than that in other treatments. The $\mathrm{N}$ uptake was significantly higher in $\mathrm{T}_{3}$ treatment $(162.6 \mathrm{Kg}$ $\mathrm{ha}^{-1}$ ) as compare to all other treatments except $\mathrm{T}_{1}$ and $\mathrm{T}_{9}$ treatments while $\mathrm{P}$ uptake $\left(13.6 \mathrm{Kg} \mathrm{ha}^{-1}\right)$ was significantly higher in $\mathrm{T}_{9}$ treatment than that in other treatments except $\mathrm{T}_{1}, \mathrm{~T}_{3}, \mathrm{~T}_{5}$ and $\mathrm{T}_{7}$ treatments. The $\mathrm{K}$ uptake was significantly higher in $\mathrm{T}_{3}$ treatment (126.9 $\mathrm{Kg} \mathrm{ha}^{-1}$ ) as compare to all other treatments except $\mathrm{T}_{1}$ and $\mathrm{T}_{9}$ treatments. The application of biofertilizers along with recommended dose of fertilizers not only improves nutrient availability but also improves the yield and protects the soil against degradation.

\section{REFERENCES}

Anonymous (2016a). Area and production of onion in India. Retrieved July, 26, 2016 from www.indiastat.com.

Anonymous (2016b). Package of Practices for cultivation of Vegetables. pp 1-2, 59-62. Punjab Agricultural University, Ludhiana.

Balemi, T., Pal, N. and Kumar, A. (2007). Response of onion (Allium cepa L.) to combined application of biological and chemical nitrogenous fertilizers. Acta Agriculturae Scandinavica, 89: 107-114

Barakade, A.J., Lokhande,T.N. and Todkari, G.U. (2011). Economics of onion cultivation and its marketing pattern in Satara district of Maharashtra. International Journal of Agricultural Statistics, 3: 110-117

Devi, H.J., Maity, T.K. and Paria, N.C. (2003). Effect of different sources of nitrogen on yield and economics of cabbage. Environment and Ecology, 21: 878-888

Gaur, V. (2010). Biofertilizer - Necessity for Sustainability. Journal of Advance Development, 1:7-8

Gerhardt, P., Murray, R.G.E., Costilow, R.N., Wood, W.A., Nester, E.W., Kreig, N.R. and Phillips, G.B. (1981). Manual of methods for general bacteriology, Washington: American Society for Microbiology.

Gupta, A.K. and Samnotra, R.K. (2004). Effects of biofertilizers and nitrogen on growth, quality and yield of cabbage (Brassica oleracea var. capitata) cv. Golden acre. Environment and Ecology, 22: 551-553

Jackson, M.L. (1967). Soil Chemical Analysis, pp.134-65, 429-51. Prentice Hall of India Pvt. Ltd. New Delhi.

Javoreková, S., Maková, J., Medo, J., Kovácsová, S., Charousová, I., Horák, J. (2015). Effect of bio-fertilizers application on microbial diversity and physiological profiling of microorganisms in arable soil. Eurasian Journal of Soil Science, 6: 54-61

Jayathilake, P.K.S., Reddy,I.P., Srihari, D. and Reddy, R. (2002). Effect of nutrient management on growth, yield and yield attributes of rabi onion (Allium cepa L.). Vegetable Science, 29: 184-185

Kachari, M. and Korla, B.N. (2009). Effect of biofertilizers on growth and yield of cauliflower cv. PSBK-1. Indian Journal of Horticulture, 66: 496-501

Kalyani, D.P., Sankar, C.R., Pillai, R.N. and Parsad, D.M. (1992). Studies on the effect of nitrogen and Azospirillum on dry matter and nutrient uptake of cauliflower. Vegetable Science, 19: 147-151

Kannaiyan, S. (2002). Biofertilizers for sustainable crop production, In: Kannayan (ed) Biotechnology of Biofertilizers. pp. 9-49. Narosa Publication House, New Delhi.

Kanwar, S.S., Gupta, M.K. and Punj, V. (1997). Laboratory manual of basic microbiology, Department of Microbiology, Collage of Basic Sciences, Himachal Pradesh Krishi Vishvavidyala, Palampur.

Mandic, L., Djukic, D., Beatovic, I., Jovovic, Z., Pesakovic, M. and Stevovic, V. (2011). Effect of different fertilizers and biofertilizers on the microbial activity and productivity of soil under potato cultivation. African Journal of Biotechnology, 10:6954-6960

Mengistu, F. and Singh, N. (1999). Effect of biofertilizers on growth, yield and nutrient uptake of onion (Allium cepa L.). Vegetable Science 26: 193-195

Nelson, R. and Achar, P.N. (2001). Stimulation of growth and nutrient up take by VAM fungi in Brassica oleracea var. capitata. Plant Biology, 4:277-281

Nonomura, H. and Ohara, Y. (1969). Distillation of actinomycetes in soil. A cultural method effective for both preferential isolation and enumeration of Microbiospora and Streptosporangium strains in soil. Hakko Kogaku Kaishi, 49: 895-903

Olsen, S.R., Cole, C.V., Watanabe, F.S. and Dean, L.A. (1954). Estimation of available phosphorus in soils by extraction with sodium bicarbonate. United States Department of Agriculture. pp 939. U. S. Govt. Printing Office, Washington D C.

Singh, D. and Singh, A. (2007). Role of biofertilizers in vegetable production. Intensive Agriculture. pp. 24-26. Krishi Vigyan Kendra, Kumher (Bhartapur) Rajasthan.

Subbiah, B.V. and Asija, C.L. (1965). A rapid procedure for the estimation of available nitrogen in soils. Current Science, 2: 259-268

Walkley, A. and Black, C.A. (1934). An examination of the Degtijareff method for determining soil organic matter and a proposed modification of the chromic acid titration method. Indian Journal of Soil Science, 37: 27-38.

Yadav, B.D., Khandelwal, R.B., and Sharma, Y.K. (2004). Use of biofertilizers (Azospirillum) in onion. Haryana Journal of Horticulture Science, 33: 281-283

Zandavalli, R.B.D., Dillenburg, L.R. and Desouza, P.V.D. (2004). Growth responses of Araucaria angustifolia inoculation with the mycorrhizal fungus Glomusclarum. Applied Soil Ecology, 25:245-255 